\title{
DIABETES MELLITUS AND RETINAL VEIN OCCLUSION IN PATIENTS OF ASIAN, WEST INDIAN AND WHITE EUROPEAN ORIGIN
}

\author{
P. M. DODSON, E. E. KRITZINGER, C. G. CLOUGH \\ Birmingham
}

\begin{abstract}
SUMMARY
The incidence of retinal vein occlusion (RVO) is known to be related to several cardiovascular risk factors including diabetes mellitus, hypertension and hyperlipidaemia. We have assessed the prevalence of these risk factors in Caucasian $(\mathrm{N}=\mathbf{5 3 6}$, mean age $=\mathbf{6 5 . 2 1}$ years $)$, West Indians $(\mathrm{N}=24$, mean age $=57.3$ years $)$ and Asian $(N=28$, mean age $=\mathbf{5 1 . 4}$ years) patients presenting with RVO.

We found no significant differences between the three groups in the distribution of hyperlipidaemia, but diabetes mellitus was more common amongst both the Asians and $W$. Indians $(10 \% \mathrm{v} 29 \%$ and $38 \%, p<0.01$ and $\mathbf{p}<\mathbf{0 . 0 0 1}$ ). Hypertension was also more common in both the Asians and the West Indians $(59 \%$ v $64 \%$ and $83 \% \mathrm{~m}$ $\mathrm{p}<0.001$ and $\mathrm{p}<0.0001$ ).

The Asians and West Indians presenting with RVO were significantly younger and had significantly higher body mass index than their Causcasian counterparts (Ethnic origin, BMI, mean age: Asian, 28.1 \pm 4.3, 51.5 \pm 12.3 years; West indian: $30.2 \pm 7.7,57.3+10$ years; White: $24.8 \pm 4.2,65.2 \pm 11.4$ years).

In this study RVO occurred at a younger age in Asians and West Indians, and was associated with a greater prevalence of diabetes mellitus and hypertension. The prevalence of hyperlipidaemia was no different in the three groups.
\end{abstract}

Occlusion of the retinal veins is an important cause of visual loss, particularly in middle age. ${ }^{1}$ The major medical conditions underlying retinal vein occlusion (RVO) include hypertension, hyperlipidaemia and diabetes mellitus. ${ }^{2.3}$ Rarer causes include myeloma, vasculitis and oestrogen-containing contraceptive preparations. ${ }^{4}$

Previous research into RVO has predominantly focussed on middle aged and young patients of white

Department of Medicine, East Birmingham Hospital and Medical Ophthalmology Clinic, Birmingham and Midland Eye Hospital, Birmingham.

Correspondence to: Dr. P. M. Dodson, MD, MRCP, Undergraduate Centre, East Birmingham Hospital, Bordesley Green East, Birmingham B9 5ST.
European origin. Conditions underlying RVO are predominantly hyperlipidaemia in young patients $(<50$ years of age) and hypertension in middle aged and elderly subjects ( $>50$ years). ${ }^{5}$ During these studies, the rarity of Asian and West Indian subjects in a group of 214 patients presenting with RVO over a four year period in two major ophthalmological centres was noted. In particular, no West Indian subject was identified with the central form of retinal venous occlusion. ${ }^{5}$ So few patients of Asian or West Indian origin were identified that scientific comparison to white Europeans was not possible. However, in view of the differing patterns of cardiovascular disease in these ethnic minority groups, further investigation was suggested to attempt to elucidate this finding further.

We have therefore identified Asian and West Indian patients compared to white European patients presenting with RVO over a seven-year period (i.e. a large study population) to allow comparative study of prevalence and underlying medical factors.

\section{PATIENTS AND METHODS}

All patients presenting to the medical ophthalmology clinic between 1982-1989 with retinal vein occlusion were sequentially recorded and examined. Diagnosis was confirmed by ophthalmoscopy, retinal photography and/or fluorescein angiography by senior ophthalmological staff (E.E.K.). Patients had a detailed medical history and physical examination performed (P.M.D. and C.G.C.) with particular emphasis on cardiovascular status, and drug, smoking, and alcohol history. Clinical parameters including body mass index, blood pressure, presence of absent pulses (or bruits) were recorded. Blood pressure was taken with either an Accouson Mercury Sphygmomanometer or Random Zero Sphygmomanometer after five minutes rest and was repeated on two further occasions if there was an initial hypertensive recording. Appropriate cuff correction was made for obese patients. ${ }^{6}$

Routine clinical chemistry was performed including renal and liver function, fibrinogen, gamma glutaryl trans- 
Table I. Clinical details of patients presenting with RVO according to ethnic group

\begin{tabular}{|c|c|c|c|}
\hline & $\begin{array}{l}\text { White } \\
\text { Europeans }\end{array}$ & Asians & $\begin{array}{l}\text { West } \\
\text { Indians }\end{array}$ \\
\hline Number of patients & 536 & 28 & 24 \\
\hline Sex & 286 & 11 & $\begin{array}{l}11 \\
23\end{array}$ \\
\hline $\begin{array}{l}\text { Mean Age } \\
\text { (years) }\end{array}$ & $\begin{array}{c}65.2 \\
( \pm 11.4)\end{array}$ & $\begin{array}{c}51.4 \dagger \\
( \pm 12.3)\end{array}$ & $\begin{array}{r}57.3 \dagger \\
( \pm 10.1)\end{array}$ \\
\hline \multicolumn{4}{|l|}{ Type of RVO: } \\
\hline BRVO & 270 & 16 & $19^{*}$ \\
\hline CRVO & 221 & 10 & 4 \\
\hline Recurrent & 45 & 2 & 1 \\
\hline $\begin{array}{l}\text { Mean Body Mass Index } \\
\left.\text { (Weight }(\mathrm{kg})-/ \mathrm{Ht}^{2}(\mathrm{~m})\right)\end{array}$ & $\begin{array}{c}24.8 \\
( \pm 4.2)\end{array}$ & $\begin{array}{c}28 \dagger \\
( \pm 4.3)\end{array}$ & $\begin{array}{l}30.2 \\
( \pm 7.6) \dagger\end{array}$ \\
\hline
\end{tabular}

${ }^{*} \mathrm{p}<0.05 \dagger \mathrm{p}<0.001$ by chi-squared or unpaired $t$-test. Figures are mean \pm standard deviation.

ferase, full blood count and ESR. Following an overnight fast, a blood sample was taken for blood glucose, serum cholesterol and triglyceride estimation.

For purposes of this study, classification of patients groups according to ethnic origin was into those of European extract (Whites), West Indian (Blacks) and of the Asian subcontinent (Asians). Definitions included the World Health Organisation for hypertension (systolic $>160 \mathrm{mmHg}$, diastolic $>95 \mathrm{mmHg}$ ) on three occasions or if the patient was already established on anti-hypertensive drug therapy. ${ }^{7}$ Hyperlipidaemia was defined according to the criteria of the British Hyperlipidaemia Association as fasting serum cholesterol $>6.5 \mathrm{mmol} / \mathrm{l}$ and/or serum triglyceride levels $>2.1 \mathrm{mmol} / 1 .{ }^{8}$

Data from this large study population was computerised using an IBM compatible data base and analysed by the Oxstat Statistical Package. Unpaired p-test and chisquared test were the statistical tests used to assess the significance of results.

\section{RESULTS}

During the seven-year-period, a total of 588 patients with

Table II. Prevalence (\%) of underlying medical conditions in patients with RVO according to ethnic group

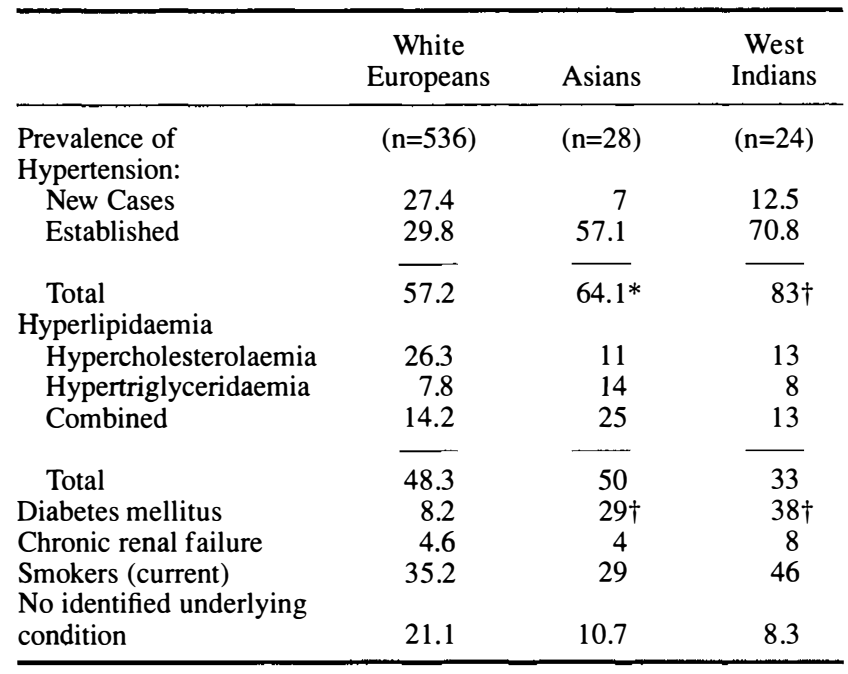

Figures are all percentages. Statistical comparisons by chi-squared test. $*_{p}<0.01 \quad \dagger p<0.001$.
RVO were seen and documented. Of these, twenty-eight patients were of Asian and twenty-four of West Indian origin. The clinical details of the five hundred and thirty-six white European patients in comparison are shown in Table I.

In this large study group, RVO appeared rare in Asian or West Indian subjects. In these two ethnic groups, patients had a male preponderance, were significantly younger, and with increased body weight and obesity compared to white Europeans with RVO. The branch form of RVO was significantly more common in West Indians, with the central form being rare. The prevalence of bilateral RVO was similar at first presentation to the clinic at $8.4 \%$ (white European), $7.1 \%$ (Asian), but less common at $4.2 \%$ in West Indian subjects.

Comparing the prevalence of underlying medical conditions in the three groups, several significant differences are shown in Table II. Hypertension and diabetes mellitus were more common in both Asian and West Indian subjects. In particular, West Indians with RVO had strikingly increased prevalence rates with $83 \%$ hypertensive and $38 \%$ diabetic. Established hypertension was more frequently identified than in white European subjects. Only $8 \%$ of West Indian subjects presenting with RVO did not have an identifiable underlying medical condition on investigation. Mean levels of blood pressure, ESR, fibrinogen, gamma-GT and MCV were not significantly different. The percentage of the three ethnic groups with RVO who were current smokers was similar (White $35.3 \%$, Asian $28.6 \%$, West Indian $37.5 \%$ ), as was regular alcohol intake assessed on history, (\% with $>1$ unit/day) at $37.5 \%$ in West Indians and $25.3 \%$ Whites, but lower in Asian subjects (7.1\%).

With regard to fasting serum lipid levels the Asian group had the highest mean serum triglyceride but lowest cholesterol values. Although there was no significant difference between the total prevalence of hyperlipidaemia between the ethnic groups, there was a trend to an increased prevalence of hypertriglyceridaemia in Asian subjects with RVO, and less hypercholesterolaemia in both Asian and West Indians compared to white Europeans.

Table III. Mean levels of blood pressure and biochemical parameters in the three ethnic groups of patients with RVO

\begin{tabular}{lccc}
\hline & $\begin{array}{c}\text { White } \\
\text { Europeans }\end{array}$ & Asians & $\begin{array}{c}\text { West } \\
\text { Indians }\end{array}$ \\
\hline Mean values & $(\mathrm{n}=536)$ & $(\mathrm{n}=28)$ & $(\mathrm{n}=24)$ \\
Blood pressure & & & \\
$\quad$ Systolic & $165.8 \pm 28.6$ & $153.4 \pm 26.1$ & $165.4 \pm 31.4$ \\
$\quad$ Diastolic & $91.0 \pm 12$ & $93.3 \pm 13.3$ & $92.8 \pm 12.3$ \\
Biochemical levels & & & \\
Fasting serum cholesterol & $6.4 \pm 1.4$ & $6.1 \pm 1.2$ & $6.3 \pm 1.2$ \\
Fasting serum triglyceride & $1.6 \pm 0.8$ & $2.4 \pm 2.3$ & $1.5 \pm 0.8$ \\
ESR & $14.9 \pm 14.4$ & $15.7 \pm 16.4$ & $15.5 \pm 12.9$ \\
Fibrinogen & $4.1 \pm 1.4$ & $3.97 \pm 1.0$ & $4.3 \pm 1.2$ \\
Gamma-glutaryl transferase & $36.4 \pm 34$ & $44.9 \pm 51.7$ & $43.8 \pm 34.1$ \\
Mean corpuscular volume & $87.9 \pm 8.7$ & $\mathbf{8 8 . 2} \pm 6.8$ & $94.2 \pm 2.1$ \\
\hline
\end{tabular}

Figures: Mean \pm SD.

$\mathrm{ESR}=$ erythrocyte sedimentation rate ( $\mathrm{mm}$ fall in first hour). 


\section{DISCUSSION}

The important findings of the study are that retinal vein occlusion occurred at a younger age in Asian and West Indian subjects and was associated with a greater prevalence of diabetes mellitus and hypertension than in the white European.

In support of earlier preliminary data, retinal vein occlusion appears rare in the ethnic minority population that we have studied in Birmingham. ${ }^{5}$ The exact reasons for these differences are not clear. The rarity of RVO in the ethnic minority groups is an unexpected finding in view of the relatively large number of immigrants (14\%) found in population surveys of the West Midlands, in whom at least $14 \%$ are between 50 years and retirement age, an age when most cases of retinal vein occlusion present. ${ }^{9.10}$ Although it would not be expected to see a similar number of patients of the ethnic minorities represented compared to the white Europeans, the differences still appear disproportionate.

With regard to underlying medical conditions in the three ethnic groups, several aspects warrant discussion. Hypertension is common in West Indian subjects, often severe and difficult to control. ${ }^{11}$ These data may explain the relative excess of the branch form of RVO seen in West Indian subjects, as this type of RVO is well known to relate to hypertension. Further support to this is the finding of chronic renal impairment being twice as frequent in the West Indian group relating to hypertension, suggesting the more severe nature of the disease. Diabetes mellitus is significantly more common in Asians than white Europeans, and was identified in one-third of West Indian patients with RVO. The former observation is less surprising in view of the increased prevalence of diabetes mellitus in the Asian population resident in the UK at 3 to 4 times greater than in white Europeans. ${ }^{12.13}$ The marked increase in West Indian subjects is statistically and clinically significant as there does not appear to be a major difference in population rates. ${ }^{14}$

Recent reports have demonstrated that hyperlipidaemia, in particular hypertriglyceridaemia, is half as prevalent in West Indian populations compared to white Europeans. ${ }^{15,16} \mathrm{~A}$ similar trend is shown in the West Indian patients with RVO. This might explain the relatively small numbers of patients presenting with the central form of $\mathrm{RVO}$, as this form is well documented to relate to hyperlipidaemia with a lesser link to hypertension. ${ }^{2}$ Hyperlipidaemia was present in half the cases of Asian RVO, which in combination with diabetes would give rise to a prevalence rate of the central form of RVO comparable to white Europeans.

Previous studies have hinted at an aetiological relationship between smoking, alcohol intake and RVO. ${ }^{2,3,17}$ Our data have demonstrated that RVO occurs in a population who denied significant alcohol intake and had a low prevalence of smoking (Asian group) but equally occurs in a group with significant daily alcohol and cigarette con- sumption (West Indian group). This therefore suggests a less important role for these two factors in RVO.

We conclude that RVO occurs at a younger age in West Indian and Asian subjects, and with a greater prevalence of diabetes mellitus and hypertension. Despite a large study population of patients with RVO, this condition appears uncommon in the ethnic minority groups resident in the United Kindgom, and in particular, the central form of RVO in West Indian subjects.

\section{REFERENCES}

1. Sorsby A: The incidence and causes of blindness in England and Wales 1963-1968. Reports on Public Health and Medical Subjects No 28. London, Her Majesty's Stationery Office, 1976

2. Dodson PM, Galton DJ, Hamilton AM, Black RK: Retinal vein occlusion and the prevalence of lipoprotein abnormalities. Br J Ophthalmol 1982, 66: 161-4.

3. Dodson PM and Kritzinger EE: Management of retinal vein occlusion. Br Med J 1987, 295: 1434-5.

4. Kohner EM, Shiling JS: Retinal Vein Occlusion. In: Medical Ophthalmology. Ed. Clifford Rose, Chapman and Hall. London, 1976.

5. Dodson PM and Kritzinger EE. Underlying medical conditions in young patients and ethnic differences in retinal vein occlusion. Trans Ophthalmol Soc UK 1985, 104: 114-19.

6. Maxwell MH, Waks AV, Schroth PC et al: Error in blood pressure measurement due to incorrect cuff size in obese patients. Lancet 1982, ii: 33-6.

7. World Health Organisation. Report of a W.H.O. Expert Committee on Hypertension. W.H.O. Technical Report Series, 1979.

8. British Hyperlidpidaemia Association: Detection and Management of blood lipid disorders. Curr Sci London 1990.

9. Johnson MRD, Cross M, Cardew SA: Inner-city residents, ethnic minorities and primary health care. Post Med J 1983, 59: 664-7.

10. Blakemore K: Ethnicity, self reported illness and use of medical services by the elderly. Post Med J 1983, 59: 668-70.

11. Cruickshank JK and Beevers DG: Epidemiology of hypertension. Clin Sci 1982, 62: 1-6.

12. Mather HM and Keen H: The Southall Diabetes Survey: prevalence of known diabetes in Asians and Europeans. $\mathrm{Br}$ Med J 1985, 291: 1081-4.

13. Simmons D, Williams DRR, Powell MJ: Prevalence of diabetes in a predominantly Asian community: preliminary findings of the Coventry Diabetes Study. Br Med J 1989, 289: $18-21$.

14. Jackson WPV: Epidemiology of diabetes in South Africa. Adv Metab Disord 1978, 9: 111-46.

15. Meade TW, Brosovic M, Chakraborti R, Haines AP, North WRS, Stirling Y: Ethnic group comparisons of variables associated with ischaemic heart disease. Br Heart J 1978, 40: 789-95.

16. Bronte-Stuart B, Keys A, Brock JF, Moodie AD, Keys MH, Antonis A: Serum cholesterol, diet and coronary artery disease. An inter-racial survey in the Cape Peninsula. Lancet 1955, ii: $1103-8$.

17. Ellis CJ, Hamer DB, Hunt RW, Lever AF et al: Medical investigation of retinal vascular occlusion. $\mathrm{Br}$ Med J 1964, ii: $1093-8$. 